\title{
ANALISIS FAKTOR-FAKTOR YANG MEMPENGARUHI INDEKS HARGA SAHAM GABUNGAN DI BURSA EFEK INDONESIA PERIODE 2012-2014
}

\author{
Dwi Purwaningsih \\ dwipurwaningsih1992@gmail.com \\ Universitas Ahmad Dahlan \\ Tina Sulistiyani \\ Tina.uad@yahoo.com \\ Universitas Ahmad Dahlan
}

\begin{abstract}
ABSTRAK
This study aims to determine the effect of the money supply, inflation, and SBI interest rates partially and simultaneously on the composite stock price index on the Indonesia Stock Exchange (BEI) in 2012-2014, the type of data and data sources used in this study are data secondary data from the Bank Indonesia Annual Report, the Indonesian Ministry of Trade Institute, and Exchange Corner Financial Data. To analyze the data of this study used a multiple linear regression analysis tool that aims to determine the effect of the money supply, inflation, and SBI interest rates on the Composite Stock Price Index using SPSS statistical tools. Based on this research, the research method used in the first hypothesis is the Statistical $t$ test and the second is the Statistical $F$ test. Based on the results of this study indicate that the variable Money Supply has a significant effect on the Composite Stock Price Index. For the inflation variable does not have a significant effect on the Composite Stock Price Index. And the SBI Interest Rate variable has a significant effect on the Composite Stock Price Index. Together these three independent variables (Amount of Money Supply, Inflation, SBI Interest Rates) have a significant influence on the dependent variable (Composite Stock Price Index).
\end{abstract}

Kata Kunci : Total Money Supply, Inflation and SBI Interest Rates

\section{PENDAHULUAN}

Salah satu pasar yang berperan cukup signifikan di Indonesia dalam mendorong pertumbuhan ekonomi adalah pasar modal. Pasar modal merupakan sarana perusahaan untuk meningkatkan kebutuhan dana jangka panjang dengan menjual saham atau mengeluarkan obligasi. Pasar modal juga mempunyai fungsi sarana alokasi dana yang produktif untuk memindahkan dana dari pemberi pinjaman ke peminjam. Alokasi dana yang produktif terjadi jika individu yang mempunyai kelebihan dana dapat meminjamkannya ke individu lain yang lebih produktif yang membutuhkan dana.
Sebab akibatnya, peminjam dan pemberi pinjaman akan lebih menguntungkan dibandingkan jika pasar modal tidak ada. Pasar modal juga menyediakan fasilitas transfer dan diantara peminjam dan pemberi pinjaman (Jogiyanto, 2003).

Menurut Keppres No. 60 tahun 1988 menjelaskan bahwa pasar modal dipahami sebagai "bursa", sarana yang mempertemukan penawar dan peminta dana jangka panjang (lebih dari satu tahun) dalam bentuk efek. Bursa efek adalah pihak yang menyelenggarakan dan menyediakan sistem dan sarana untuk mempertemukan penawaran jual dan beli efek kepada pihak-pihak lain dengan tujuan memperdagangkan efek. Efek yang 
dimaksud adalah surat berharga, yaitu surat pengakuan utang, surat berharga komersial, saham, obligasi, tanda bukti utang, Unit Penyertaan kontrak investasi kolektif, kontrak berjangka atas Efek, dan setiap (UU. No 8 tahun 1995). Bursa efek merupakan lembaga penghimpun dana terbesar kedua setelah perbankan, dan memainkan peran penting dalam perekonomian suatu negara sebagai bagian dari lembaga keuangan (non keuangan) yang mampu mengalokasi sumber dana masyarakat. Peran penting yang dimainkan bursa efek yang menghubungkan secara langsung dalam bentuk transaksi sekuritas antara pihak perusahaan dalam hal ini kalangan industri yang memerlukan dana dengan melepaskan sebagian saham kepemilikkan dan pihak investor yang ingin menanamkan modalnya untuk tujuan meraih keuntungan, dari sudut pandang pembiayaan lebih efisien dibandingkan dana yang ditawarkan pihak perbankan lewat fungsi intermediasinya (Muis, 2008)

Di Bursa Efek Indonesia terdapat beberapa faktor makro yang mempengaruhi aktifitas investasi saham diantaranya adalah jumlah uang beredar, tingkat inflasi, tingkat suku bunga SBI (Sertifikat Bank Indonesia), dan lainnya. Bursa efek juga memiliki indeks-indeks yang tercatat di dalamnya salah satunya adalah indeks harga saham gabungan dimana indeks ini merupakan suatu indeks diperlukan sebagai msebuah indikator untuk mengamati pergerakan harga dari sekuritas-sekuritas (Jogiyanto, 2003). Menurut penelitian yang dilakukan Zulhidiawati (2006) bahwa tingginya suku bunga SBI maupun deposito berakibat negatif terhadap pasar modal, karena return tahun yang diterima lebih kecil dibandingkan dengan pendapatan dari bunga deposito, akibatnya harga-harga saham (IHSG) di pasar modal sejak bulan Agustus 1997 selalu menurun. Laju inflasi yang terlalu tinggi mengganggu usaha pemerintah dalam meningkatkan taraf hidup masyarakat. Inflasi juga dapat merangsang pertumbuhan ekonomi melalui transfer sumber-sumber dari masyarakat kepada investor. Inflasi yang tinggi dapat berdampak terhadap ketidakstabilan politik di dalam negara, sedangkan pasar modal juga dipengaruhi oleh faktor politik di dalam negeri.

Selain suku bunga dan jumlah uang beredar, Indeks Harga Saham Gabungan juga dipengaruhi oleh faktor-faktor lain, yaitu laju inflasi dan nilai tukar rupiah terhadap mata uang asing. Faktor nonekonomi seperti; kondisi politik, baik dalam negeri maupun luar negeri, keamanan, dan kebijakan-kebijakan pemerintah juga berpengaruh terhadap Indeks Harga Saham Gabungan. Suku bunga dan inflasi mempunyai pengaruh yang negatif terhadap Indeks Harga Saham Gabungan, pada saat suku bunga perbankan naik, maka ada kecenderungan para pemodal atau masyarakat lebih memilih mengalihkan dananya pada sektor perbankan sehingga selera berinvestasi menjadi berkurang. Hal ini yang mengakibatkan terjadinya penurunan Indeks Harga Saham Gabungan. Hal yang sama terjadi pada inflasi, tingginya inflasi menjadi penanda bagi ketidakstabilan perekonomian suatu negara. Kestabilan ini pula mendorong menurunnya Indeks Harga Saham Gabungan.

Sedangkan menurut penelitian yang dilakukan Listriani (2008) bahwa pergerakan suku bunga SBI yang fluktuatif dan cenderung meningkat juga mempengaruhi pergerakan sektor rill yang dicerminkan oleh pergerakan harga saham. Kondisi yang dipaparkan diawal sangat mendukung pandangan bahwa nilai tukar rupiah dan SBI mempunyai dampak pada pasar modal di Indonesia. Selain kurs dan tingkat suku bunga, tingkat inflasi dan jumlah uang beredar juga berpengaruh terhadap harga saham. Tingkat inflasi yang meningkat akan mengurangi kekuatan daya beli rupiah yang telah diinvestasikan, oleh karenanya risiko inflasi juga bisa disebut sebagai risiko daya beli. Jika inflasi mengalami peningkatan, investor biasanya menuntut tambahan premium 
inflasi untuk mengkompensasikan penurunan daya yang dialaminya. Suku bunga dan inflasi mempunyai pengaruh negatif terhadap Indeks Harga Saham Gabungan pada saat suku bunga perbankan naik maka ada kecenderungan para pemodal atau masyarakat lebih memilih mengalihkan dananya pada sektor perbankan sehingga selera berinvestasi menjadi berkurang. Sedangkan jumlah uang beredar dapat berpengaruh positif terhadap harga saham. Ketika jumlah uang beredar meningkat dan tingkat suku bunga sedang menurun hal ini jelas menunjukkan bahwa masyarakat lebih memilih memegang uang untuk diinvestasikan.

\section{Rumusan Masalah}

1. Apakah Jumlah Uang Beredar (JUB), Inflasi, dan Suku Bunga SBI secara parsial berpengaruh terhadap Indeks Harga Saham Gabungan di Bursa Efek Indonesia periode 2012-2014 ?

2. Apakah Jumlah Uang Beredar (JUB),Inflasi, dan Suku Bunga SBI secara bersama-sama (simultan) berpengaruh terhadap Indeks Harga Saham Gabungan di Bursa Efek Indonesia periode 2012-2014?

\section{REVIEW LITERATUR DAN HIPOTESIS}

\section{Landasan Teori}

\section{Pengertian Pasar Modal}

Pasar modal adalah tempat diperjualbelikannya berbagai instrumen keuangan jangka panjang, seperti; utang, ekuitas (saham), instrumen derivatif, dan instrumen lainnya. Pasar modal juga merupakan sarana pendanaan bagi perusahaan maupun institusi lain (misalnya pemerintah), dan berbagai sarana bagi kegiatan berinvestasi. Dengan demikian pasar modal memfasilitasi berbagai sarana dan prasarana kegiatan jual beli dan kegiatan terkait lainnya (Darmadji dan Fakhruddin, 2011).

\section{Instrumen Pasar Modal}

Menurut Rusdin (2008, 76-82), beberapa sekuritas yang umumnya diperdagangkan di pasar modal adalah:

a. Saham

Saham adalah sertifikat yang menunjukkan bukti kepemilikan suatu perusahaan dan pemegang saham memiliki hak klaim atas penghasilan dan aktiva perusahaan.

b. Obligasi

Obligasi adalah sertifikat yang berisi kontrak antara investor dan perusahaan, yang menyatakan bahwa investor tersebut atau pemegang obligasi telah meminjamkan sejumlah uang kepada perusahaan. Perusahaan yang menerbitkan obligasi mempunyai kewajiban untuk membayar bunga secara regular sesuai jangka waktu yang telah ditetapkan serta pokok pinjaman setelah jatuh tempo.

c. Reksa Dana

Reksa dana adalah saham, obligasi, atau efek lain yang dibeli oleh sejumlah investor dan dikelola oleh sebuah perusahaan investor profesional.

d. Produk Derivatif

Derivatif merupakan instrumen yang sangat berisiko jika tidak dipergunakan secara hati-hati. Derivatif terdiri dari efek yang diturunkan dari instrumen efek lain yang disebut "underlying".

\section{Jenis-jenis Pasar Modal}

Dalam Jogiyanto (2003: 15-16), pasar modal mempunyai beberapa jenis, yaitu:

a) Pasar Primer (Primary Market)

Pasar primer ini terjadi pada saat surat berharga yang baru dikeluarkan oleh perusahaan dijual. Surat berharga yang baru dijual dapat berupa penawaran perdana ke publik (Initial Public Offering atau IPO) atau tambahan surat berharga baru jika perusahaan sudah go publik.12

b) Pasar sekunder (Secondary Market)

Pasar sekunder merupakan tempat perdagangan surat berharga yang sudah 
beredar, dimana pasar ini terjadi apabila surat berharga sudah diperdagangkan di pasar sekunder.

c) Pasar Ketiga (Third Market)

Pasar ketiga merupakan pasar perdagangan surat berharga pada saat pasar kedua tutup. Pasar ketiga dijalankan oleh broker yang mempertemukan pembeli dan penjual pada saat pasar kedua tutup.

d) Pasar Keempat (Fourth Market)

Pasar keempat merupakan pasar modal yang dilakukan diantara institusi berkapasitas besar untuk menghindari komisi untuk broker. Pasar ini pada umumnya menggunakan jaringan komunikasi untuk menggunakan jaringan komunikasi untuk memperdagangkan saham dalam jumlah blok besar.

\section{Peranan Pasar Modal}

Menurut Sunariyah (2006, 9-10), Ditinjau dari makro ekonomi atau dalam kehidupan sehari-hari, pasar modal mempunyai peranan yang lebih luas jangkauannya. Peranan pasar modal dalam suatu perekonomian negara adalah sebagai berikut:

a. Fungsi Tabungan (Savings Function)

Bagi penabung cenderung sangat dipengaruhi oleh kemungkinan rugi sebagai akibat penurunan nilai mata uang, inflasi, risiko hilang, dan lainlain. Apabila seseorang ingin mempertahankan nilai sejumlah uang yang dimilikinya, maka perlu mempertimbangkan agar kerugian yang diderita tetap minimal. Dengan melihat gambaran tersebut, para penabung perlu memikirkan alternatif menabung ke wilayah lain yaitu investasi. Surat berharga yang diperdagangkan di pasar modal memberi jalan yang begitu murah dan mudah, tanpa risiko untuk menginvestasikan dana. Dengan membeli surat berharga, masyarakat diharapkan bisa mengantisipasi standar hidup yang lebih baik. b. Fungsi Kekayaan (Wealth Function)

Pasar modal adalah suatu cara untuk menyimpan kekayaan dalam jangka panjang maupun jangka pendek sampai dengan kekayaan tersebut dapat dipergunakan kembali.

c. Fungsi Likuiditas (Liquiditas Function)

Kekayaaan yang disimpan dalam surat-surat berharga, bisa dilikuidasi melalui pasar modal dengan risiko yang sangat minimal dibandingkan dengan aktiva lain. Dengan kata lain, pasar modal adalah ready market untuk melayani pemenuhan likuiditas para pemegang surat berharga.

d. Fungsi Pinjaman (Credit Function)

Pasar modal merupakan fungsi pinjaman untuk konsumsi atau investasi. Pinjaman merupakan hutang kepada masyarakat. Pasar modal bagi perekonomian negara merupakan sumber pembiayaan pembangunan dari pinjaman yang dihimpun dari masyarakat. Pemerintah lebih mendorong pertumbuhan pasar modal untuk mendapatkan dana yang lebih mudah dan lebih murah.

\section{Pengertian Indeks Harga Saham}

Menurut Tandelilin, (2010), Indeks harga saham merupakan indikator yang mencerminkan kinerja saham-saham di pasar, karena merupakan indikator yang menggambarkan pergerakan harga-harga saham. Sedangkan menurut Sunariyah (2006), indeks harga saham merupakan catatan terhadap perubahan-perubahan maupun pergerakan harga saham sejak mulai pertama kali beredar sampai pada suatu saat tertentu. Rumus Indeks Harga Saham Gabungan

$$
\text { IHSG }_{\mathrm{t}}=\frac{\text { Nilai Pasar }_{t}}{\text { Nilai Dasar }} \times 100
$$

Notasi:

IHSGt = Indeks harga saham

Nilai Pasar $=$ Rata-rata tertimbang nilai pasar (jumlah lebar tercatat di bursa dikalikan dengan harga pasar perlembarnya) 
dari saham umum dan saham preferen pada hari ke-t.

Nilai Dasar $=$ Sama dengan nilai pasar tetapi dimulai dari tanggal 10 Agustus 1982

Dengan demikian Indeks Harga Saham Gabungan untuk tanggal 10 Agustus 1982 adalah bernilai 100 (nilai ini merupakan indeks dasar) nilai dasar dari Indeks Harga Saham Gabungan selalu disesuaikan untuk kejadian seperti IPO, right issues, partial/company listing, konversi dari warrant, convertible bond, dan delisting (mengundurkan diri dari pencatatan misalnya karena kebangkrutan). Untuk kejadian-kejadian seperti pemecahan lembar saham (stock splits), deviden berupa saham (stock dividends), bonus issue, nilai dasar dari IHSG tidak berubah karena peristiwaperistiwa ini tidak merubah nilai pasar total. Rumus untuk menyesuaikan nilai dasar adalah sebagai berikut:

$$
\mathrm{NDB}=\frac{\text { NPL }+ \text { NPTS }}{\text { NPL }} \times \text { NDL }
$$

Notasi:

NDB = Nilai dasar baru yang disesuaikan

NPL $=$ Nilai pasar lama

NPTS $=$ Nilai pasar tambahan saham

NDL = Nilai dasar lama

\section{Jenis-jenis Indeks Harga Saham}

Menurut Tandelilin (2010, 86-89), jenis-jenis indeks harga saham

diuraikan sebagai berikut:

a. Indeks Harga Saham Gabungan, menggunakan seluruh saham tercatat sebagai komponen perhitungan indeks, dimana masing-masing pasar modal memiliki indeks yang dibentuk berdasarkan saham-saham yang dipakai sebagai dasar dalam perhitungan indeks harga.

b. Indeks LQ45, terdiri dari 45 saham di BEI dengan likuiditas yang tinggi dan kapitalisasi pasar yang besar serta lolos seleksi menurut beberapa kriteria pemilihan. c. Indeks Kompas 100, pada prinsipnya sama dengan LQ-45, yakni terkait dengan isu likuiditas saham. Dalam hal ini yang dipakai dalam perhitungan adalah 100 saham teraktif dengan memilih $\quad 100 \quad$ saham mempertimbangkan frekuensi transaksi, kapitalitas pasar, dan kinerja fundamental dari saham-saham tersebut.

d. Indeks Sektoral, menggunakan semua saham yang termasuk dalam masingmasing sektor. Semua saham yang tercatat di BEI diklarifikasikan ke dalam sembilan sektor menurut klarifikasi industri yang telah ditetapkan BEI, dan BEI juga menghitung indeks industri manufaktur yang merupakan industri gabungan dari tiga sektor industri, maka hasilnya adalah 10 indeks sektoral.

e. Jakarta Islam Indeks, sebagai tolak ukur untuk mengukur kinerja investasi pada saham dengan basis Syariah dan diharapkan dapat meningkatkan kepercayaan investor untuk berinvestasi secara Syariah. JII terdiri dari 30 jenis saham yang dipilih dari saham-saham yang sesuai dengan Syariah Islam dan termasuk saham yang likuid.

f. Indeks Papam Utama dan Indeks Papan Pengembangan, kedua indeks ini dikeluarkan BEJ untuk menggunakan indikator dalam memantau perkembangan sahamsaham yang masuk dalam masingmasing pencatatan.

\section{Faktor yang Mempengaruhi Indeks Harga Saham Gabungan}

a. Jumlah Uang Beredar (JUB)

Uang beredar adalah semua jenis uang yang berada di perekonomian, yaitu adalah jumlah dari mata uang dalam peredaran ditambah dengan uang giral dalam bank-bank umum. Uang beredar dalam pengertian luas ini juga dinamakan dengan $\mathrm{M} 2$, dan pengertian sempit uang beredar selalu disingkat 
dengan M1 (Sukirno, 1998). Jumlah uang beredar merupakan jumlah seluruh uang kartal yang dipegang anggota masyarakat dan "demand deposite" yang dimiliki perseorangan pada Bankbank Umum. Ini berarti pemegangan uang kartal dipengaruhi oleh besar kecilnya demand deposite. Alasan21 pemegangan uang kartal karena adanya kenaikan secara umum pinjamanpinjaman bank dan deposito yang dipengaruhi oleh kenaikan di dalam kegiatan perekonomian (Iswardono, 1999). Jika jumlah uang beredar meningkat, maka tingkat bunga akan menurun dan Indeks Harga Saham Gabungan akan naik sehingga pasar akan menjadi bullish. Jika jumlah uang beredar menurun, maka tingkat bunga akan naik dan Indeks Harga Saham Gabungan akan turun sehingga pasar akan menjadi bearish (Samsul, 2006).

b. Inflasi

Inflasi adalah proses kenaikan harga-harga umum barang-barang secara terus menerus. Ini tidak berarti bahwa harga-harga berbagai macam barang itu naik dengan persentase yang sama. Mungkin dapat terjadi kenaikan tersebut tidaklah bersamaan. Yang penting terdapat kenaikan harga umum barang secara terus menerus selama suatu periode tertentu (Nopirin, 2000: 25). Tingkat inflasi yang tinggi biasanya dikaitkan dengan kondisi ekonomi mengalami permintaan atas produk yang melebihi kapasitas penawaran produknya, sehingga hargaharga cenderung mengalami kenaikan. Inflasi yang terlalu tinggi juga akan menyebabkan penurunan pada daya beli uang. Di samping itu, inflasi yang tinggi juga bisa mengurangi tingkat pendapatan riil yang diperoleh investor dari investasinya, sebaliknya jika tingkat inflasi suatu negara mengalami penurunan, maka hal ini akan merupakan sinyal positif bagi investor seiring dengan turunnya risiko daya beli uang dan risiko dan penurunan pendapatan riil (Tandelilin, 2010: 342).

\section{c. Suku Bunga SBI}

Sertifikat Bank Indonesia (SBI) pertama sekali diterbitkan tahun 1970 dan hanya diperdagangkan antarbank. Namun kebijaksanaan ini tidak berlangsung lama, karena pemerintah mengeluarkan kebijaksanaan untukmemperkenankan bank-bank umum untuk menerbitkan sertifikat deposito tahun 1971. SBI diterbitkan kembali dengan keluarnya kebijaksanaan deregulasi perbankan 1 juni 1983 (Kasmir, 2002). SBI diterbitkan dan dijual oleh BI untuk mengelola kelebihan uang primer tersebut. Selain itu juga, suku bunga yang tinggi tentunya akan berdampak pada alokasi dana investasi para investor. Investasi produk bank seperti deposito atau tabungan jelas lebih kecil resikonya dibandingkan investasi dalam bentuk saham. Sehingga investor akan menjual sahamnya dan kemudian akan menyimpan dananya di bank. Penjualan saham yang serentak akan berdampak pada penurunan harga secara signifikan (Arifin, 2007). Suku bunga adalah harga dana yang dapat dipinjamkan besarnya ditentukan oleh preferensi dan sumber pinjaman berbagai pelaku ekonomi di pasar. Suku bunga tidak hanya dipengaruhi oleh perubahanpreferensi para pelaku ekonomi, dalam hal pinjaman dan pemberian23 pinjaman, tetapi juga dipengaruhi perubahan daya beli uang. Karena suku bunga pasar atau suku bunga yang berlaku berubah dari waktu ke waktu dan suku bunga kapan dari kebanyakan obligasi jangka panjang ditetapkan pada waktu penerbitannya maka harga saham berubah-ubah sesuai perubahan suku bunga (Boediono, 2001).

d. Nilai Tukar (Kurs) Rupiah

Kurs atau nilai tukar adalah harga dari mata uang luar negeri (Dornbusch et.al., 2008). Kurs mata uang menunjukkan harga mata uang apabila 
ditukarkan dengan mata uang lain. Penentuan nilai kurs mata uang suatu negara dengan mata uang negeri lain ditentukn sebgai mana halnya barang yaitu oleh permintaan dan penawaran mata uang yang bersangkutan. Hukum ini juga berlaku untuk kurs rupiah, jika demand akan rupiah lebih banyak dari pada suplainya maka kurs rupiah ini akan terapresiasi, demikin pula sebaliknya. Apresiasi atau depresisi akan terjadi apabila negra menganut kebijakan nilai tukar mengambang bebas sehingga nilai tukar akan ditentukan oleh mekanisme pasar (Kuncoro, 2001).

e. Gross Domestic Products (GDP)

Gross Domestic Products dapat diartikn sebagai nilai pasar semua barang dan jsa akhir yang diproduksikan di dalam suatu Negara atau perekonomian dalam kurun waktu tertentu (Mankiw, 2003 dalam Wijayanti, 2013). GDP mengindikasikan pertumbuhan ekonomi, semakin tingginya GDP berarti pendapatan masyarakat meningkat, sesuai pendapat Keynes, semakin tinggi pendapatan seseorang maka motif permintaan uangnya makin kompleks hingga spekulatif motif. Maka GDP dan IHSG mempunyai hubungan positif atau searah (Wijayanti, 2013). Meningkatnya GDP merupakan sinyal yang baik (positif) untuk investasi dan sebaliknya. Meningkatkan PDB mempunyai pengaruh positif terhadap daya beli konsumen sehingga dapat meningkatkan permintaan terhadap produk perusahaan. Adanya peningkatan permintaan terhadap produk perusahaan akan meningkatkan profit perusahaan dan pada akhirnya dapat meningkatkan harga saham perusahaan. (Kewal, 2012).

\section{Penelitian Terdahulu}

Berikut ini beberapa penelitian terdahulu yang relevan dengan penelitian ini antara lain sebagai berikut:

1. Berdasarkan hasil analisis yang dilakukan oleh Zulhidiawati (2006) yang meneliti judul "Analisis Pengaruh JUB, Suku Bunga SBI, Kurs Valas, dan Laju Inflasi terhadap Indeks Harga Saham Gabungan di Bursa Efek Jakarta periode 1999.12005.12" diperoleh hasil sebagai berikut:

a. Secara umum untuk pengujian asumsi klasik tidak ada gejala multikolinearitas, heteroskedastisit as, dan autokorelasi terhadap Indeks Harga Saham Gabungan.

b. Secara individual menyatakan bahwa jumlah uang beredar (JUB)berpengaruh secara signifikan terhadap Indeks Harga Saham Gabungan dengan arah parameter positif, suku bunga SBI menunjukkan parameter positif dan tidak signifikan terhadap Indeks Harga Saham Gabungan,kurs tidak berpengaruh secara signifikan terhadap Indeks Harga Saham Gabungan, dan inflasi berpengaruh negatif dan tidak signifikan terhada Indeks Harga Saham Gabungan.

c. Sedangkan melalui pengujian hipotesis didapatkan secara serentak variabel JUB, suku bunga SBI, kurs, dan inflasi mempengaruhi Indeks Harga Saham Gabungan di Bursa Efek Indonesia.

2. Dari hasil analisis yang dilakukan oleh Nurdistira (2012) yang meneliti judul "Analisis Pengaruh Suku Bunga SBI, Kurs Dolar Amerika Serikat, dan Inflasi terhadap Indeks Harga Saham Gabungan di Bursa Efek Indonesia" diperoleh hasil sebagai berikut:

a. Secara individual; Suku bunga SBI tidak berpengaruh terhadap 
Indeks Harga Saham Gabungan, kurs dolar Amerika Serikat berpengaruh signifikan terhadap Indeks Harga Saham Gabungan, dan inflasi berpengaruh signifikan terhadap Indeks Harga Saham Gabungan.

b. Secara simultan, ketiga variabel independen (suku bunga SBI, kurs dolar Amerika Serikat, dan inflasi) ini berpengaruh signifikan terhadap variabel dependen (Indeks Harga Saham Gabungan).

3. Dari hasil jurnal yang dilakukan oleh Amin (2012) yang meneliti judul "Pengaruh Tingkat Inflasi, Suku Bunga SBI, Nilai Kurs Dollar (USD/IDR), dan Indeks Dow Jones (DJIA) terhadap Pergerakan Indeks Harga Saham Gabungan di Bursa Efek Indonesia (BEI) Periode 20082011" diperoleh hasil sebagai berikut:

a. Secara individual; Tingkat inflasi tidak berpengaruh secara parsial terhadap terhadap Indeks Harga Saham Gabungan, tingkat suku bunga SBI berpengaruh positif terhadap Indeks Harga Saham Gabungan, nilai kurs dollar AS terhadap rupiah berpengaruh negatif terhadap Indeks Harga Saham Gabungan, indeks Dow Jones (DJIA) berpengaruh positif terhadap Indeks Harga Saham Gabungan, dan tingkat suku bunga SBI berpengaruh paling dominan terhadap Indeks Harga Saham Gabungan dibandingkan dengan variabel independen yang lain.

b. Tingkat inflasi, tingkat suku bunga SBI, nilai kurs U.S dollar (USD/IDR), Indeks Dow Jones (DJIA) berpengaruh secara simultan terhadap Indeks Harga Saham Gabungan.

\section{Hipotesis}

H1: Ada pengaruh secara parsial antara Jumlah Uang Beredar (JUB) terhadap Indeks Harga Saham Gabungan

$\mathrm{H} 2$ : Ada terdapat pengaruh secara parsial antara Inflasi terhadap Indeks Harga Saham Gabungan

H3: Ada pengaruh secara parsial Suku Bunga SBI terhadap Indeks Harga Saham Gabungan

H4: Ada pengaruh secara bersama-sama (simultan) antara jumlah uang beredar (JUB), Inflasi, dan Suku Bunga SBI terhadap Indeks Harga Saham Gabungan.

\section{METODE PENELITIAN}

\section{Populasi dan Sampel}

Penelitian pada analisis ini adalah Indeks Harga Saham Gabungan, Jumlah Uang Beredar (JUB), Inflasi, dan Suku Bunga SBI selama 3 (tiga) tahun dari tanggal 1 Januari 2012 sampai 31 Desember 2014, Saham seluruh perusahaan tersebut digabungkan dan di rata-rata menjadi Indeks Harga Saham Gabungan.

\section{Definisi Operasional}

Variabel adalah suatu atribut atau sifat dari obyek atau kegiatan yang memiliki variasi tertentu yang ditetapkan oleh peneliti untuk dipelajari dan ditarik kesimpulannya (Sugiyono, 2012). Berkait dengan penelitian ini, variabel penelitian akan terbagi menjadi dua yang terdiri dari variabel dependen yang digunakan adalah Indeks Harga Saham Gabungan dan variabel independen yang digunakan adalah jumlah uang beredar (JUB), inflasi, dan suku bunga SBI. Penjelasan masingmasing variabel akan dijelaskan sebagai berikut:

1. Variabel Independen

\section{Indeks Harga Saham Gabungan (IHSG)}

IHSG adalah indikator untuk mengukur harga saham yang diperdagangkan di bursa efek dengan dasar tahun 1989 yang 
dinyatakan dalam satuan Rupiah per tahun.

2. Variabel Dependen

\section{Jumlah Uang Beredar (JUB)}

JUB yang digunakan dalam penelitian ini adalah uang kartal dan uang giral yang beredar dalam masyarakat dalam bentuk milyar. Data JUB dalam arti35 sempit karena uang dalam arti seperti ini lebih banyak digunakan masyarakat dalam transaksi seharihari. Data yang diperoleh dari laporan Bank Indonesia.

\section{Inflasi}

Menurut Boediono (2001), Inflasi adalah kecenderungan naiknya harga secara umum dan terus menerus dalam waktu dan tempat tertentu. Tingkat inflasi yang digunakan adalah laju inflasi secara umum perbulan selama periode penelitian bulan Januari 2012 sampai Desember 2014.

\section{Suku Bunga SBI}

Tingkat suku bunga SBI yang digunakan dalam penelitian ini adalah suku bunga berjangka dalam waktu perbulan yang diperoleh dari Laporan Bank Indonesia dengan rentan waktu dari bulan Januari 2012 sampai dengan Desember 2014.

\section{Teknik Analisis Data}

1. Analisis Regresi Berganda

Data Analisis Regresi $\begin{gathered}\text { Linier } \\ \text { untuk }\end{gathered}$
Berganda varianakan
menghubungkan beberapa variabel
bebas atau independen variabel (X)
terhadap satu variabel tidak bebas atau
dependen variabel (Y) dengan model
yang linear. Formula untuk regresi
linier berganda untuk populasi secara
umum ditunjukkan dengan persamaan
sebagai berikut:

$$
\begin{aligned}
\mathbf{Y}= & \mathbf{a}+\mathbf{b}_{1} \mathbf{x}_{1}+\mathbf{b}_{2} \mathbf{x}_{2}+\mathbf{b}_{3} \mathbf{x}_{3}+\boldsymbol{e} \\
\text { Dimana: } & \\
\mathrm{Y}= & \text { Indeks Harga Saham Gabungan } \\
\mathrm{a}= & \text { Konstanta } \\
\mathrm{b} 1= & \text { Koefisien regresi untuk variabel } \\
& \text { Jumlah Uang Beredar }(\mathrm{JUB}) \\
\mathrm{b} 2= & \text { Koefisien regresi untuk variabel } \\
& \text { Inflasi } \\
\mathrm{b} 3= & \text { Koefisien regresi untuk variabel } \\
& \text { Suku Bunga SBI } \\
\mathrm{X} 1= & \text { Jumlah Uang Beredar (JUB) } \\
\mathrm{X} 2= & \text { Inflasi } \\
\mathrm{X} 3= & \text { Suku Bunga SBI } \\
\mathrm{e}= & \text { Error }
\end{aligned}
$$

\section{Uji Hipotesis}

\section{Uji Parsial (Uji T)}

Menurut Ghozali (2006), tujuan pengujian ini adalah untuk mengetahui seberapa jauh pengaruh satu variabel independen (jumlah uang beredar, inflasi, dan suku bunga SBI) dalam menerangkan variasi variabel dependen (Indeks Harga Saham Gabungan) secara terpisah ataupun bersama-sama. Untuk uji $t$ ini, perlu menggunakan langkahlangkah sebagai berikut:

1). Merumuskan nilai hipotesis Ho dan hipotesis alternatif $\mathrm{Ha}$ :

a) Ho : $\beta=0$, artinya tidak ada pengaruh antara variabel jumlah uang beredar (JUB), inflasi, dan suku bunga SBI terhadap Indeks Harga Saham Gabungan.

b) Ha : $\beta \neq 0$, artinya ada pengaruh antara variabel jumlah uang beredar (JUB), inflasi, dan suku bunga SBI terhadap Indeks Harga Saham Gabungan.

2) Menentukan t signifikan:

Perhitungan statistik dilakukan dengan bantuan program SPSS (Statistical Product and Service Solution) vs 16.0.

3) Menentukan taraf signifikan $(\alpha)=5 \%$ atau 0,05 dengan uji dua sisi pengujian

4) Membuat daerah kesimpulan dan kriteria pengujian :

a) Apabila t. sign (probabilitas) $>0,05$ maka Ho diterima dan $\mathrm{Ha}$ ditolak. 
Artinya: tidak ada pengaruh antara jumlah uang beredar, inflasi, dan suku bunga SBI terhadap Indeks Harga Saham Gabungan.

b) Apabila t. sign (probabilitas) $<0,05$ maka Ho ditolak dan $\mathrm{Ha}$ diterima. Artinya: ada pengaruh antara jumlah uang beredar, inflasi, dan suku bunga SBI terhadap Indeks Harga Saham Gabungan.

\section{Uji Simultan (Uji F)}

Uji $F$ pada dasarnya menunjukkan apakah semua variabel bebas yang dimasukkan dalam model mempunyai pengaruh secara bersamasama terhadap variabel dependen atau terikat (Ghozali, 2006). Dalam penelitian ini pengujian hipotesis secara simultan atau tidak yang dimaksudkan untuk mengukur besarnya pengaruh jumlah uang beredar (JUB), inflasi, dan suku bunga SBI terhadap Indeks Harga Saham Gabungan. Adapun kriteria pengujian uji $\mathrm{F}$ adalah sebagai berikut:

1). Merumuskan hipotesis:

a) Ho: $\beta=0$, artinya tidak ada pengaruh secara serentak antara variabel jumlah uang beredar (JUB), inflasi, dan suku bunga SBI terhadap Indeks Harga Saham Gabungan.

b) Ha: $\beta \neq 0$, artinya ada pengaruh secara serentak antara variabel jumlah uang beredar (JUB), inflasi, dan suku bunga SBI terhadap Indeks Harga Saham Gabungan.

2). Menentukan F signifikan:

Perhitungan dilakukan dengan menggunakan program SPSS (Statistical Product and Service Solution) vs 16.0.

3). Menentukan $F$ tabel dengan tarafsignifikan $(\alpha)=5 \%$ atau 0,05 dan derajat kebebasan $\mathrm{df}=(\mathrm{n}-\mathrm{k}-\mathrm{l})$.

4). Menentukan daerah kesimpulan sign. (probabilitas) dengan kriteria pengujian: a) Apabila probabilitas $>0,05$ maka Ho diterima dan Ha ditolak. Artinya: tidak ada pengaruh antara jumlah uang beredar, inflasi, dan suku bunga SBI terhadap Indeks Harga Saham Gabungan.

b) Apabila probabilitas $<0,05$ maka Ho ditolak dan Ha diterima.

Artinya: ada pengaruh antara jumlah uang beredar, inflasi, dan suku bunga SBI terhadap Indeks Harga Saham Gabungan.

\section{HASIL PENELITIAN DAN PEMBAHASAN}

\section{Hasil Analisis Penelitian}

Pada analisis hasil penelitian ini variabel yang digunakan untuk data penelitian yang terdiri dari Jumlah Uang Beredar, Inflasi, dan Suku Bunga SBI sebagai variabel independen dan Indeks Harga Saham Gabungan sebagai variabel dependen menggunakan nilai rata-rata bulanan yang dijadikan data penelitian.

\section{Variabel Jumlah Uang Beredar (JUB)}

Pada jangka panjang hubungan jumlah uang beredar dengan Indeks Harga Saham Gabungan berpengaruh positif dan signifikan. Jika jumlah uang beredar dalam masyarakat semakin banyak maka akan mendorong kemajuan ekonomi dan akan meningkatkan Indeks Harga Saham Gabungan, hal ini dikarenakan kelebihan uang yang dipegang masyarakat, sehingga mereka membelanjakan (membeli saham barang dan jasa) dari kelebihan uang tersebut (Zulhidiawati, 2006). Adapun data jumlah uang beredar yang dijelaskan ke dalam tabel sebagai berikut: 
Tabel 4.1

Data Jumlah Uang Beredar Bulanan Secara Nasional Periode Januari 2012 - Desember 2014

\begin{tabular}{|l|l|l|l|}
\hline Bulan dan Tahun & JUB & Bulan dan Tahun & JUB \\
\hline Januari 2012 & $2.827 .570,00$ & Juli 2013 & $3.506 .574,00$ \\
\hline Februari 2012 & $2.849 .796,00$ & Agustus 2013 & $3.502 .420,00$ \\
\hline Maret 2012 & $2.911 .920,00$ & September 2013 & $3.584 .017,00$ \\
\hline April 2012 & $2.927 .259,00$ & Oktober 2013 & $3.576 .318,00$ \\
\hline Mei 2012 & $2.992 .057,00$ & November 2013 & $3.614 .519,66$ \\
\hline Juni 2012 & $3.050 .355,00$ & Desember 2013 & $3.727 .695,59$ \\
\hline Juli 2012 & $3.054 .836,00$ & Januari 2014 & $3.649 .270,00$ \\
\hline Agustus 2012 & $3.089 .011,00$ & Februari 2014 & $3.639 .494,00$ \\
\hline September 2012 & $3.125 .533,00$ & Maret 2014 & $3.656 .440,00$ \\
\hline Oktober 2012 & $3.161 .726,00$ & April 2014 & $3.732 .093,00$ \\
\hline November 2012 & $3.205 .129,00$ & Mei 2014 & $3.784 .861,00$ \\
\hline Desember 2012 & $3.304 .645,00$ & Juni 2014 & $3.861 .659,00$ \\
\hline Januari 2013 & $3.265 .869,00$ & Juli 2014 & $3.891 .434,00$ \\
\hline Februari 2013 & $3.277 .426,00$ & Agustus 2014 & $3.887 .553,76$ \\
\hline Maret 2013 & $3.319 .468,00$ & September2014 & $4.009 .856,51$ \\
\hline April 2013 & $3.357 .823,00$ & Oktober 2014 & $4.024 .152,54$ \\
\hline Mei 2013 & $3.423 .155,00$ & November 2014 & $4.076 .294,16$ \\
\hline Juni 2013 & $3.413 .437,00$ & Desember 2014 & $4.170 .730,79$ \\
\hline \\
Sumber: SERI BL, Processed by Trade Data and Infarmation Center, Ministry of Trade \\
(wwwe-bemendag
\end{tabular}

Dilihat dari tabel di atas, pada pada tahun 2012 tercatat jumlah uang beredar yang terjadi mencapai Rp 3.304.645, yakni pada bulan Desember. Sebaliknya pada tahun yang sama, penurunan jumlah uang beredar sebesar Rp 2.827.570 yang terjadi pada bulan Januari. Pada tahun 2013 jumlah uang beredar mengalami kenaikan mencapai angka Rp 3.727.695,59 yakni pada bulan43 Desember, sebaliknya yang mengalami penurunan jumlah uang beredar sebesar Rp 3.265.869 yang terjadi pada bulan Februari. Pada tahun 2014 terjadi kenaikan jumlah uang beredar semakin menunjukkan angka Rp 4.170.730,79 yang terjadi pada bulan Desember, sebaliknya yang mengalami penurunan sebesar Rp 3.639.494 yakni pada bulan februari.

\section{Variabel Inflasi}

Menurut Nopirin (2000), inflasi adalah proses kenaikan harga-harga umum barang-barang secara terus menerus. Jika peningkatan biaya lebih tinggi dari peningkatan harga yang dapat dinikmati oleh perusahaan maka profitabilitas perusahaan akan turun. Maka peningkatan inflasi secara relatif merupakan sinyal negatif bagi pemodal di pasar modal dengan kata lain kenaikan inflasi mempunyai pengaruh negatif terhadap Indeks Harga Saham Gabungan (Tandelilin, 2001). Adapun data inflasi yang dijelaskan ke dalam tabel sebagai berikut:

\begin{tabular}{|c|c|c|c|}
\hline \multicolumn{4}{|c|}{ Periode Januari 2012 - Desember 2014} \\
\hline Bulan dan Tahun & \begin{tabular}{|l|l} 
Inflasi \\
\end{tabular} & Bulan dan Tahun & Inflasi \\
\hline Januari 2012 & 3.65 & Juli 2013 & 8.61 \\
\hline Februari 2012 & 3.56 & Agustus 2013 & 8.79 \\
\hline Maret 2012 & 3.97 & September 2013 & 8.40 \\
\hline April 2012 & 4.50 & Oktober 2013 & 8.32 \\
\hline Mei 2012 & 4.45 & November 2013 & 8.37 \\
\hline Juni 2012 & 4.53 & Desember 2013 & 8.38 \\
\hline Juli 2012 & 4.56 & Januari 2014 & 8.22 \\
\hline Agustus 2012 & 4.58 & Februari 2014 & 7.75 \\
\hline September 2012 & 4.31 & Maret 2014 & 7.32 \\
\hline Oktober 2012 & 4.61 & April 2014 & 7.25 \\
\hline November 2012 & 4.32 & Mei 2014 & 7.32 \\
\hline Desember 2012 & 4.30 & Juni 2014 & 6.70 \\
\hline Januari 2013 & 4.57 & Juli 2014 & 4.53 \\
\hline Februari 2013 & 5.31 & Agustus 2014 & 3.99 \\
\hline Maret 2013 & 5.90 & September 2014 & 4.53 \\
\hline April 2013 & 5.57 & Oktober 2014 & 4.83 \\
\hline Mei 2013 & 5.47 & November 2014 & 6.23 \\
\hline Juni 2013 & 5.90 & Desember 2014 & 8.36 \\
\hline
\end{tabular}

Dilihat dari tabel di atas, pada pada tahun 2012 tercatat tingkat inflasi yang terjadi mencapai $4,61 \%$ yakni pada bulan Oktober. Sebaliknya pada tahun yang sama, penurunan harga (deflasi) mencapai tingkat $3,56 \%$ yang terjadi pada bulan Februari. Pada tahun 2013 inflasi yang semakin menunjukkan angka $8,79 \%$ yakni pada bulan Agustus. Sebaliknya yang mengalami penurunan harga mencapai tingkat $4,57 \%$ yang terjadi pada bulan Januari. Pada tahun 2014 terjadi kenaikan harga mencapai angka $8,22 \%$ yang terjadi pada bulan Januari, sebaliknya yang mengalami deflasi mencapai angkat 3,99\% yakni pada bulan Agustus.

\section{Variabel Suku Bunga SBI}

Suku bunga adalah harga dana yang dapat dipinjamkan besarnya ditentukan oleh preferensi dan sumber pinjaman berbagai pelaku ekonomi di pasar. Suku bunga tidak hanya dipengaruhi oleh perubahan preferensi para pelaku ekonomi dalam hal pinjaman dan pemberian pinjaman, tetapi juga dipengaruhi perubahan daya beli uang. Karena suku bunga pasar atau suku bunga yang berlaku berubah dari waktu ke waktu dan suku bunga kapan dari kebanyakan obligasi jangka panjang ditetapkan pada waktu 
penerbitannya maka harga saham berubahubah sesuai perubahan suku bunga (Boediono, 2001). Adapun data suku bunga SBI yang dijelaskan ke dalam tabel sebagai berikut:

Tabel 4.3

Suku Bunga SBI (Dalam Persen) Bulanan Secara Nasional Periode Januari 2012 - Desember 2014

\begin{tabular}{|l|l|l|l|}
\hline Bulan dan Tahun & Suku Bunga & Bulan danTahun & Suku Bunga \\
\hline Januari 2012 & 6.00 & Juli 2013 & 6.50 \\
\hline Februari 2012 & 5.75 & Agustus 2013 & 7.00 \\
\hline Maret 2012 & 5.75 & September 2013 & 7.25 \\
\hline April 2012 & 5.75 & Oktober 2013 & 7.25 \\
\hline Mei 2012 & 5.75 & November 2013 & 7.50 \\
\hline Juni 2012 & 5.75 & Desember 2013 & 7.50 \\
\hline Juli 2012 & 5.75 & Januari 2014 & 7.50 \\
\hline Agustus 2012 & 5.75 & Februari 2014 & 7.50 \\
\hline September 2012 & 5.75 & Maret 2014 & 7.50 \\
\hline Oktober 2012 & 5.75 & April 2014 & 7.50 \\
\hline November 2012 & 5.75 & Mei 2014 & 7.50 \\
\hline Desember 2012 & 5.75 & Juni 2014 & 7.50 \\
\hline Januari 2013 & 5.75 & Juli 2014 & 7.50 \\
\hline Februari 2013 & 5.75 & Agustus 2014 & 7.50 \\
\hline Maret 2013 & 5.75 & September 2014 & 7.50 \\
\hline April 2013 & 5.75 & Oktober 2014 & 7.50 \\
\hline Mei 2013 & 6.00 & November 2014 & 7.75 \\
\hline Juni 2013 & 6.50 & Desember 2014 & 7.75 \\
\hline Sumber: Data Keuangan 81 (wrow bigoid) periode 2012 - 2014 \\
\hline
\end{tabular}

Dilihat dari tabel di atas, dijelaskan bahwa pada tahun 2012 tercatat tingkat suku bunga yang terjadi mencapai angka 6\% yakni pada bulan Januari. Akan tetapi pada tahun yang sama, penurunan suku bunga menunjukkan angka 5,75\% yang terjadi pada bulan Januari sampai bulan Desember. Pada tahun 2013 mengalami kenaikan suku bunga mencapai angka $7,50 \%$ yakni pada bulan47 November dan Desember. Sebaliknya yang mengalami penurunan suku bunga menunjukkan tingkat $5,75 \%$ yang terjadi pada bulan Januari sampai bulan April. Dan pada tahun 2014 terjadi kenaikan suku bunga mencapai angka $7,75 \%$ yang terjadi pada bulan November dan Desember, sebaliknya yang mengalami penurunan suku bunga menunjukkan angka 7,50\% yakni pada bulan Januari sampai Oktober.

\section{Variabel Indeks Harga Saham Gabungan}

Beberapa faktor-faktor yang mempengaruhi indeks harga saham suatu perusahaan dan faktor-faktor tersebut sangat mendominasi pergerakan harga saham. Menurut Jogiyanto (2003), suatu indeks diperlukan sebagai sebuah indikator untuk mengamati pergerakan harga dari sekuritas-sekuritas. Berikut ini adalah Indeks Harga Saham Gabungan bulanan yang tercatat di Bursa Efek Indonesia periode 2012-2014, yang dijelaskan ke dalam tabel sebagai berikut:

$$
\text { Tabel } 4.4
$$

Rata-rata Indeks Harga Saham Gabungan Bulanan Periode Januari 2012 - Desember 2014

\begin{tabular}{|l|l|l|l|}
\hline Bulan dan Tahun & IHSG & Bulan dan Tahun & IHSG \\
\hline Januari 2012 & $3,941.69$ & Juli 2013 & $4,610.38$ \\
\hline Februari 2012 & $3,985.21$ & Agustus 2013 & $4,195.09$ \\
\hline Maret 2012 & $4,121.55$ & September 2013 & $4,316.18$ \\
\hline April 2012 & $4,180.73$ & Oktober 2013 & $4,510.63$ \\
\hline Mei 2012 & $3,832.82$ & November 2013 & $4,256.44$ \\
\hline Juni 2012 & $3,955.58$ & Desember 2013 & $4,274.18$ \\
\hline Juli 2012 & $4,142.34$ & Januari 2014 & $4,418.76$ \\
\hline Agustus 2012 & $4,060.33$ & Februari 2014 & $4,620.22$ \\
\hline September 2012 & $4,262.56$ & Maret 2014 & $4,768.28$ \\
\hline Oktober 2012 & $4,350.29$ & April 2014 & $4,840.15$ \\
\hline November 2012 & $4,276.14$ & Mei 2014 & $4,893.91$ \\
\hline Desember 2012 & $4,316.69$ & Juni 2014 & $4,878.58$ \\
\hline Januari 2013 & $4,453.70$ & Juli 2014 & $5,088.80$ \\
\hline Februari 2013 & $4,795.79$ & Agustus 2014 & $5,136.86$ \\
\hline Maret 2013 & $4,940.99$ & September 2014 & $5,137.58$ \\
\hline April 2013 & $5,034.07$ & Oktober 2014 & $5,089.55$ \\
\hline Mei 2013 & $5,068.63$ & November 2014 & $5,149.89$ \\
\hline Juni 2013 & $4,818.90$ & Desember 2014 & $5,226.95$ \\
\hline Sumber: Data Keuangan BEI (www.finance.vahoo.com) periode 2012 - 2014
\end{tabular}

Dilihat dari tabel di atas, tercatat di tahun 2012 tingkat Indeks Harga Saham Gabungan tertinggi sebesar Rp 4.350,29 yang terjadi pada bulan Oktober. Sebaliknya pada tahun yang sama, Indeks Harga Saham Gabungan terendah menunjukkan angka $\mathrm{Rp} 3.832,82$ yang terjadi pada bulan Mei. Pada tahun 2013 tingkat Indeks Harga Saham Gabungan tertinggi tercatat pada bulan Mei sebesar49 Rp 5.068,63. Sedangkan Indeks Harga Saham Gabungan terendah menunjukkan angka Rp 4.195,09 yang terjadi pada bulan Agustus. Pada tahun 2014 terjadi Indeks Harga Saham Gabungan tertinggi mencapai angka Rp 5.226,95 yang terjadi pada bulan Desember, sedangkan yang mengalami Indeks Harga Saham Gabungan terendah sebesar Rp 4.418,76 yakni pada bulan Januari. Hal ini secara keseluruhan Indeks Harga Saham Gabungan yang mengalami peningkatan paling tinggi tercatat di tahun 2014 mencapai Rp 5.226,95. Sedangkan angka Indeks Harga Saham Gabungan terendah 
yakni menunjukkan angka $\mathrm{Rp} 3.832,82$ di tahun 2012.

\begin{tabular}{|c|c|c|}
\hline \multicolumn{3}{|c|}{$\begin{array}{l}\text { Hasil Penelitian } \\
\text { Analisis Regresi }\end{array}$} \\
\hline \multirow{3}{*}{$\begin{array}{l}\text { Coefficients }^{2} \\
\text { Model }\end{array}$} & & \\
\hline & \multicolumn{2}{|c|}{ Unstandardized Coefficients } \\
\hline & B & Std. Error \\
\hline (Constant) & 1246.741 & 325.505 \\
\hline $\mathrm{X}_{1} \_\mathrm{J}$ & .002 & .000 \\
\hline $\mathrm{X}_{2}$ INFLASI & -33.386 & 26.018 \\
\hline $\begin{array}{l}\mathrm{X}_{3} \text { SSUKU_BUNGA_ } \\
\text { SBI }\end{array}$ & & 102.885 \\
\hline
\end{tabular}

Berdasarkan hasil regresi di atas, berikut persamaan regresi berganda:

$\mathrm{Y}=1.246,741+0,002 \mathrm{X} 1-33,386 \mathrm{X} 2$ $379,570 \times 3$

Dilihat dari persamaan diatas dapat disimpulkan melalui intrepestasi dengan taraf signifikan 5\% adalah sebagai berikut:

\section{Nilai Konstanta}

Konstanta (a) sebesar 1.246,741 yang dapat diartikan bahwa jika tidak ada pengaruh jumlah uang beredar, inflasi, dan suku bunga SBI maka Indeks Harga Saham Gabungan sebesar 1.246,74 satuan.

2. Koefisien Regresi Jumlah Uang Beredar Koefisien regresi X1 sebesar 0,002 menyatakan bahwa setiap kenaikan variabel jumlah uang beredar sebesar 1 satuan memberikan kenaikan Indeks Harga Saham Gabungan sebesar 0,002 satuan, sebaliknya jika setiap penurunan variabel jumlah uang beredar sebesar 1 satuan maka penurunan Indeks Harga Saham Gabungan sebesar 0,002 satuan.

3. Koefisiensi Regresi Inflasi

Koefisien regresi X2 sebesar -33,39 menyatakan bahwa setiap kenaikan variabel inflasi sebesar 1 satuan maka memberikan penurunan Indeks Harga Saham Gabungan sebesar 33,39 satuan, sebaliknya jika setiap penurunan variabel inflasi sebesar 1 satuan maka memberikan kenaikan Indeks Harga Saham Gabungan sebesar 33,39 satuan.

4. Koefisiensi Regresi Suku Bunga SBI

Koefisien regresi X3 sebesar -379,57 menyatakan bahwa setiap kenaikan varaiabel suku bunga SBI sebesar 1 satuan maka memberikan penurunan
Indeks Harga Saham Gabungan sebesar 379,57 satuan, sebaliknya jika setiap penurunan varaiabel suku bunga SBI sebesar 1 satuan maka memberikan peningkatan Indeks Harga Saham Gabungan sebesar 379,57 satuan.

\section{Pengujian Hipotesis \\ Uji Normalitas \\ Tabel 4.5}

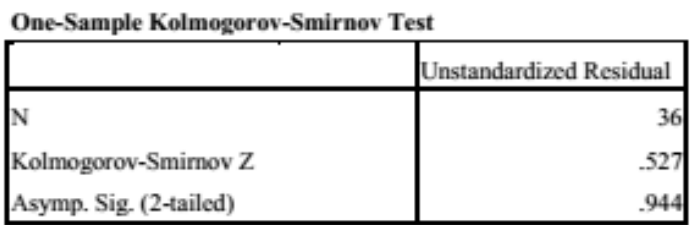

a. Test distribution is Normal.

Sumber: output SPSS diolah pada bulan Juni 2015

Berdasarkan hasil dari tabel 4.5

tersebut, dapat disimpulkan bahwa residual persamaan regresi pada penelitian ini mempunyai distribusi normal, karena angka signifikansi uji KolmogorovSmirnov Sign $>\alpha(0,05)$. Hal ini terlihat pada nilai signifikan kolmogorov-smirnov sebesar 0,944 yang berarti lebih besar dari taraf signifikan 0,05.

\section{Uji t Statistik}

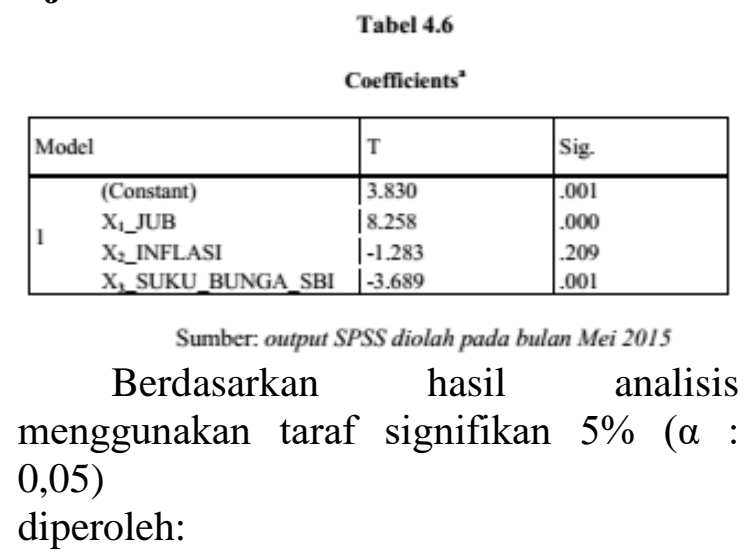

1. Pengaruh Jumlah Uang Beredar (JUB) Terhadap Indeks Harga Saham Gabungan

Hasil pengolahan analisis uji $t$ dengan menggunakan SPSS disajikan dalam perhitungan nilai hipotesis untuk masing-masing variabel independen dan variabel dependen.

a) Merumuskan nilai hipotesis $\mathrm{Ho}$ dan hipotesis alternatif Ha: Ho : $\beta=0$, artinya tidak ada pengaruh antara 
variabel jumlah uang beredar (JUB) terhadap Indeks Harga Saham Gabungan.

$\mathrm{Ha}: \beta \neq 0$, artinya ada pengaruh antara variabel jumlah uang beredar (JUB) terhadap Indeks Harga Saham Gabungan.

b) Menentukan taraf signifikan $(\alpha)=5 \%$ atau 0,05 dengan uji dua sisi pengujian

c) Membuat daerah kesimpulan dan kriteria pengujian :

Dimana probabilitas $<0,05$ (alpha) yaitu $0,000<0,05$ artinya: ada pengaruh variabel Jumlah Uang Beredar terhadap Indeks Harga Saham Gabungan maka dapat disimpulkan Ho ditolak dan Ha diterima.

\section{Pengaruh Inflasi Terhadap Indeks Harga Saham Gabungan}

Hasil pengolahan analisis uji t dengan menggunakan SPSS disajikan dalam perhitungan nilai hipotesis untuk masing-masing variabel independen dan variabel dependen. Dengan demikian dapat disimpulkan

menggunakan rumus sebagai berikut:

a) Merumuskan nilai hipotesis Ho dan hipotesis alternatif Ha: Ho : $\beta=0$, artinya tidak ada pengaruh antara variabel inflasi terhadap Indeks Harga Saham Gabungan.

$\mathrm{Ha}: \beta \neq 0$, artinya ada pengaruh antara variabel inflasi terhadap Indeks Harga Saham Gabungan.

b) Menentukan taraf signifikan $(\alpha)=0,05$ dengan uji dua sisi pengujian

c) Membuat daerah kesimpulan dan kriteria pengujian :

Dimana probabilitas > 0,05 (alpha) yaitu 0,209 > 0,05 artinya: tidak ada pengaruh variabel Inflasi terhadap Indeks Harga Saham Gabungan maka dapat disimpulkan $\mathrm{Ho}$ diterima $\mathrm{Ha}$ ditolak.

\section{Pengaruh Suku Bunga SBI Terhadap Indeks Harga Saham Gabungan}

Hasil pengolahan analisis uji $t$ dengan menggunakan SPSS disajikan dalam perhitungan nilai hipotesis untuk masing-masing variabel independen dan variabel dependen.

a) Merumuskan nilai hipotesis Ho dan hipotesis alternatif Ha: Ho : $\beta=0$, artinya tidak ada pengaruh antara variabel suku bunga SBI terhadap Indeks Harga Saham Gabungan.

Ha : $\beta \neq 0$, artinya ada pengaruh antara variabel suku bunga SBI terhadap Indeks Harga Saham Gabungan.

b) Menentukan taraf signifikan $(\alpha)=5 \%$ atau 0,05 dengan uji dua sisi pengujian

c) Membuat daerah kesimpulan dan kriteria pengujian :

Dimana probabilitas $<0,05$ (alpha) yaitu $0,001<0,05$ artinya: ada pengaruh variabel Suku Bunga SBI terhadap Indeks Harga Saham Gabungan maka dapat disimpulkan Ho ditolak Ha diterima.

\section{Uji F Statistik}

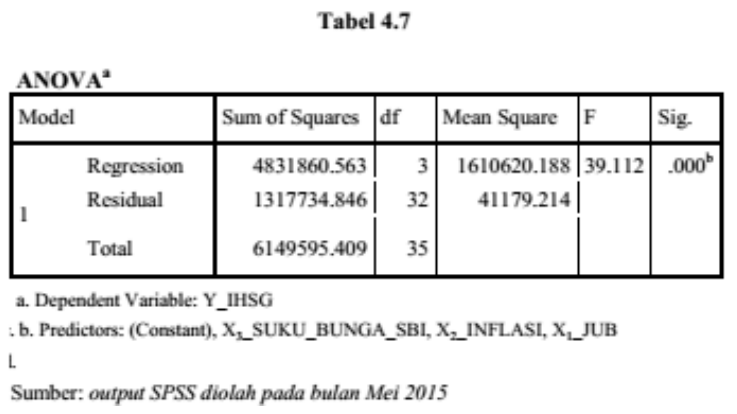

Berdasarkan uji anova atau tabel di atas, diperoleh tingkat taraf signifikan 5\% dan tingkat signifikan 0,000. Maka dapat diambil keputusan dengan cara sebagai berikut:

1. Merumuskan hipotesis:

a) Ho: $\beta=0$, artinya tidak ada pengaruh secara simlutan antara variabel jumlah uang beredar (JUB), inflasi, dan suku bunga SBI terhadap Indeks Harga Saham Gabungan.

b) Ha : $\beta \neq 0$, artinya ada pengaruh secara simultan antara variabel jumlah uang beredar (JUB), inflasi, dan suku bunga SBI terhadap Indeks Harga Saham Gabungan.

2. Menentukan F signifikan:

Menentukan $\mathrm{F}$ tabel dengan taraf signifikan $(\alpha)=5 \%$ atau 0,05 dan 
derajat kebebasan df $=(n-k-1)$. Dimana $\mathrm{df}=36-3-1=32$.

3. Menentukan daerah kesimpulan sign. (probabilitas) dengan kriteria pengujian:

Diperoleh tingkat taraf signifikan 5\% dan tingkat signifikan 0,000. Maka dapat diambil keputusan bahwa $(0,000$ $<0,05)$ artinya: ada pengaruh antara Jumlah Uang Beredar, Inflasi, dan Suku Bunga SBI secara bersama-sama (simultan) mempunyai pengaruh signifikan terhadap Indeks Harga Saham Gabungan maka dapat disimpulkan Ho ditolak Ha diterima

\section{Pembahasan}

\section{Pengaruh Jumlah Uang Beredar terhadap Indeks Harga Saham Gabungan}

Berdasarkan penelitian di atas menunjukkan bahwa variabel Jumlah Uang Beredar berpengaruh signifikan terhadap Indeks Harga Saham Gabungan dengan pengujian secara parsial yang diperoleh dari $\mathrm{t}$ hitung sebesar 8,258 dengan probabilitas 0,000 dimana setiap kenaikan variabel jumlah uang beredar sebesar 1 satuan menyebabkan kenaikan Indeks Harga Saham Gabungan sebesar 8,258 satuan. Hal ini berdasarkan hasil uji yang menunjukkan bahwa probabilitas 0,000 lebih kecil dari 0,05 (alpha) maka dapat disimpulkan Ho ditolak dan $\mathrm{Ha}$ diterima. Hasil penelitian ini mendukung penelitian Zulhidiawati (2006) dimana penelitian tersebut juga membuktikan bahwa jumlah uang beredar (JUB) berpengaruh secara signifikan terhadap Indeks Harga Saham Gabungan. Hal ini jika jumlah uang beredar meningkat, maka tingkat bunga akan menurun dan Indeks Harga Saham Gabungan maka akan mendorong kemajuan ekonomi karena uang yang dipegang masyarakat lebih digunakan untuk membeli saham barang dan jasa ketimbang menginvestasikan uangnya (Nurdistira, 2012).

\section{Pengaruh Inflasi terhadap Indeks Harga Saham Gabungan}

Berdasarkan penelitian di atas menunjukkan bahwa variabel Inflasi tidak ada pengaruh signifikan terhadap Indeks Harga Saham Gabungan dengan pengujian secara parsial yang diperoleh dari t hitung sebesar -1,283 dengan probabilitas 0,209 dimana setiap kenaikan variabel inflasi sebesar 1 satuan maka menyebabkan penurunan Indeks Harga Saham Gabungan sebesar 1,283 satuan. Hal ini berdasarkan hasil uji yang menunjukkan bahwa probabilitas 0,209 lebih besar dari 0,05 (alpha) maka dapat disimpulkan Ho diterima Ha ditolak. Hasil penelitian ini mendukung penelitian Zulhidiawati (2006) dan Amin (2012) dimana penelitian tersebut juga membuktikan bahwa inflasi tidak berpengaruh secara signifikan terhadap Indeks Harga Saham Gabungan. Hal ini disebabkan karena secara relatif mempunyai sinyal negatif59 bagi pemodal di pasar modal karena inflasi dapat menurunkan pendapatan yang disebabkan meningkatnya biaya perusahaan dan biaya produksi sehingga profitabilitas perusahaan di pasar modal mengalami penurunan maka penjualan saham juga akan mengalami. Namun tingkat inflasi yang relatif kecil dan tidak terlalu tinggi akan berdampak positif pada kegiatan pasar modal (Nurdistira, 2012).

\section{Pengaruh Suku Bunga SBI terhadap Indeks Harga Saham Gabungan}

Berdasarkan penelitian di atas bahwa variabel suku bunga SBI ada pengaruh signifikan terhadap Indeks Harga Saham Gabungan dengan pengujian secara parsial yang diperoleh dari t hitung sebesar $-3,689$ dengan probabilitas 0,001 dimana setiap kenaikan variabel suku bunga SBI sebesar 1 satuan maka menyebabkan penurunan Indeks Harga Saham Gabungan sebesar 3,689 satuan. Hal ini berdasarkan hasil uji yang menunjukkan bahwa t sign. (probabilitas) 0,001 lebih kecil dari 0,05 (alpha) maka dapat disimpulkan Ho 
ditolak Ha diterima. Hasil penelitian ini mendukung penelitian Nurdistira (2012) dimana penelitian tersebut juga membuktikan bahwa suku bunga SBI berpengaruh secara signifikan terhadap Indeks Harga Saham Gabungan. Hal ini disebabkan karena suku bunga SBI relatif tidak terlalu tinggi tidak akan terlalu berpengaruh pada kegiatan di pasar modal modal. Dengan tingginya suku bunga SBI, maka pemilik dana akan lebih cenderung memilih deposito dalam menyimpan dananya, maka hal ini akan berdampak pada harga-harga60 saham, dan jika harga saham naik maka Indeks Harga Saham Gabungan akan naik dan sebaliknya jika harga saham turun maka Indeks Harga Saham Gabungan juga akan turun. Jika suku bunga turun maka harga saham akan naik karena ketika tingkat suku bunga turun masyarakat tidak mendapatkan keuntungan dengan menabung tetapi akan mendapatkan keuntungan yang lebih dari investasi, banyaknya permintaan untuk menanamkan modal menyebabkan harga saham akan mengalami peningkatan (Listriani, 2008).

\section{Pengaruh Jumlah Uang Beredar, Inflasi, Suku Bunga SBI terhadap Indeks Harga Saham Gabungan}

Berdasarkan penelitian di atas bahwa secara simultan variabel Jumlah Uang Beredar (X1), Inflasi (X2), dan Suku Bunga SBI (X3) mempunyai pengaruh terhadap Indeks Harga Saham Gabungan (Y). Hal ini berdasarkan

hasil uji yang menunjukkan bahwa tingkat probabilitas 0,000 lebih kecil dari 0,05 (alpha) maka dapat disimpulkan Ho ditolak Ha diterima. Hasil penelitian ini mendukung penelitian Zulhidiawati (2006) dan Listriani (2008) dimana penelitian tersebut juga membuktikan bahwa serentak variabel jumlah uang beredar (JUB), inflasi, dan suku bunga SBI mempengaruhi Indeks Harga Saham Gabungan di Bursa Efek Indonesia. Hal ini dapat diketahui dari uji yang dilakukan baik secara simultan maupun secara parsial dari tiap variabel yang mempengaruhi.

\section{KESIMPULAN DAN SARAN}

\section{Kesimpulan}

Berdasarkan hasil analisis dan pembahasan pada bab IV sebelumnya, maka dapat diambil kesimpulan sebagai berikut:

1. Jumlah Uang Beredar (JUB) berpengaruh signifikan terhadap Indek Harga Saham Gabungan. Hal ini berdasarkan hasil uji yang menunjukkan bahwa probabilitas 0,000 lebih kecil dari 0,05 (alpha).

2. Inflasi tidak berpengaruh signifikan terhadap Indeks Harga Saham Gabungan. Hal ini berdasarkan hasil uji yang menunjukkan bahwa probabilitas 0,209 lebih besar dari 0,05 (alpha). 62

3. Suku Bunga SBI berpengaruh signifikan terhadap Indeks Harga Saham Gabungan. Hal ini berdasarkan hasil uji yang menunjukkan bahwa probabilitas 0,001 lebih kecil dari 0,05 (alpha).

4. Secara bersama-sama (simultan), ketiga variabel independen (Jumlah Uang Beredar, Inflasi, Suku Bunga SBI) ini mempunyai pengaruh yang signifikan terhadap variabel dependen (Indeks Harga Saham Gabungan). Hal ini berdasarkan hasil uji yang menunjukkan bahwa tingkat probabilitas 0,000 lebih kecil dari 0,05 (alpha).

\section{Saran}

a. Bagi calon investor maupun investor diharapkan dapat lebih detail dan spesifik dalam meramalkan kondisi pasar modal sebelum mengambil keputusan investasi pada saham. Dan juga diharapkan untuk dapat memanfaatkan referensi-referensi yang ada untuk digunakan sebagai peramalan dan bahan pertimbangan. 
b. Bagi penulis diharapkan hasil penelitian ini dapat memperluas pengetahuan tentang faktor-faktor apa saja yang dapat mempengaruhi Indeks Harga Saham Gabungan di Bursa Efek Indonesia.

c. Bagi penelitian selanjutnya diharapkan menambahkan panjang jangka waktu yang lama karena persistensi laba umumnya lebih akurat jika dihitung dalam periode pengamatan yang panjang (lebih dari 5 tahun) sehingga pengaruh terhadap Indeks Harga Saham Gabungan (IHSG) juga dapat dipelajari lebih baik.

\section{DAFTAR PUSTAKA}

Amin, Muhammad Zuhdi. 2012. "Pengaruh Tingkat Inflasi, Suku Bunga SBI, Nilai Kurs Dollar (USD/IDR), dan Indeks Dow Jones (DJIA) terhadap Pergerakan Indeks Harga Saham Gabungan di Bursa Efek Indonesia (BEI) Periode 20082011". Jurnal Fakultas Ekonomi dan Bisnis. Hal 16. http://jimfeb.ub.ac.id/index.php.

Diakses pada 28 Mei 2015.

Arifin, Ali. 2007. Membaca Saham. Yogyakarta: UPP AMP YKPN.

Boediono. 2001. Ekonomi Moneter. Edisi ketiga. Yogyakarta: BPFE..

Darmadji, Tjiptono dan Hendy $M$. Fakhruddin. 2011. Pasar Modal Di Indonesia. Edisi Ketiga. Jakarta: Salemba Empat.

Dornbusch, Rudiger, dkk. 2008. Makro Ekonomi. Terjemahan oleh: Roy Indra Mirazudin, S.E. Jakarta: PT Media Global Edukasi.

Ghozali, Imam. 2006. Aplikasi Analisis Multivariat dengan Program SPSS. Semarang: Badan Penerbit Universitas Diponegoro.
Gujarati, Damodar. 1997. Ekonometrika Dasar. Jakarta: Penerbit Erlangga.

Husnan, Suad. 1998. Dasar-dasar Teori Portofolio dan Analisis Sekuritas. Edisi Ketiga. Yogyakarta: UPP AMP YKPN.

Jogiyanto. 2003. Teori Portofolio dan Analisis Investasi. Edisi Ketiga. Yogyakarta: BPFE UGM.

Iswardono. 1999. Suku Bunga Diturunkan Investasi Akan Meningkat. Jurnal Ekonomi dan Bisnis Indonesia. Vol 14, No. 2, Hal 34-42. http://ilib.ugm.ac.id/jurnal/detail.php ?dataId=3843. Diakses pada 17 Juni 2015.

Kewal, Suramaya Suci. 2012. Pengaruh Inflasi, Suku Bunga, Kurs, dan Pertumbuhan PDB Terhadap Indeks Harga Saham Gabungan. Jurnal Economia (April). Vol. 8, No. 1. http://journal.uny.ac.id/index.php/ec onomia. Diakses pada 17 Juni 2015.

Kuncoro, Mudrajat. 2001. Manajemen Keuangan Internasional. Edisi Kedua. Yogyakarta: BPFE.

Listriani, Erdah. 2008. "Pengaruh Kurs, Suku Bunga, Inflasi, Posisi Dana Masyarakat, dan JUB terhadap Indeks Harga Saham Gabungan Tahun 1997.I- 2007.IV”. Skripsi. Yogyakarta: Universitas Ahmad Dahlan.

Mankiw, N. Greorgy. 2000. Teori Makro Ekonomi. Edisi Keempat. Jakarta: Erlangga

Mohamad, Samsul. 2006. Pasar Modal dan Manajemen Portofolio. Surabaya: Erlangga.

Nopirin. 2000. Ekonomi Moneter II. Edisi Pertama. Yogyakarta: BPFE. 
Nurdistira, Angga. 2012. "Analisis Pengaruh JUB, Suku Bunga SBI, Kurs Valas, dan Laju Inflasi terhadap Indeks Harga Saham Gabungan di Bursa Efek Jakarta periode 1999.1-2005.12”. Skripsi. Yogyakarta: Universitas Ahmad Dahlan.

Rusdin. 2008. Pasar Modal Teori Masalah dan Kebijakan dalam Praktik. Edisi Kedua. Bandung: ALFABETA, CV.

Sarjono, Haryadi dan Julianita, Winda. 2013. SPSS vs LISRAEL; Sebuah Pengantar, Aplikasi untuk Riset. Jakarta: Salemba Empat.

Sugiyono. 2012. Metode Penelitian Kuantitatif Kualitatif dan R \& D. Bandung: Alfabeta.

Sukirno, Sadono. 1998. Pengantar Teori Makroekonomi. PT Raja Grafindo. Jakarta: Persada.

Sulistiawati, Tri. 2010. Hubungan Kausalitas antara Inflasi dan Jumlah Uang Beredar (M1) di Indonesia Tahun 1970-2008. Skripsi. Yogyakarta: Universitas Ahmad Dahlan.

Sunariyah. 2006. Pengantar Pengetahuan Pasar Modal. Edisi Kelima. Yogyakarta: UPP-AMP.YKPN.

Tandelilin, Eduardus. 2001. Analisis Investasi dan Manajemen Portofolio. Edisi Pertama. Yogyakarta: BPFE.

Tandelilin, Eduardus. 2010. Portofolio dan Investasi; Teori dan Aplikasi. Edisi Pertama. Yogyakarta: KANISIUS.

Wijayanti, Anis. 2013. Pengaruh Beberapa Variabel Makroekonomi dan Indeks Pasar Modal Dunia terhadap Pergerakan Indeks Harga Saham Gabungan (IHSG) Di BEI. Jurnal
Ekonomi dan Bisnis. http://jimfeb.ub.ac.id/index.php. Diakses pada 17 Juni 2015.

Zulhidiawati. 2006. "Analisis Pengaruh Suku Bunga SBI, Kurs Dolar Amerika Serikat, dan Inflasi terhadap Indeks Harga Saham Gabungan di Bursa Efek Indonesia”. Skripsi. Yogyakarta: Universitas Ahmad Dahlan.

www.bi.go.id

www.finance.yahoo.id

www.kemendeg.go.id

http://www.jariungu.com/peraturan_detail .php?Keputusan-Presiden-No--60-tahun 1988-tentang-Pasar

Modal\&idPeraturan $=6113$

http://www.bapepam.go.id/desain_baru/pa sar_modal/regulasi_pm/uu_pm/index.htm. ии по. 8 